\title{
APPLICABLE LAW IN INTERNATIONAL INSOLVENCY PROCEEDINGS (FOCUSED ON THE RELATION OF ARTICLES 3 AND 7 OF THE INSOLVENCY REGULATION)
}

\author{
JAN BRODEC
}

\begin{abstract}
This article deals with the legal regulation governing the ascertaining of applicable law under the Insolvency Regulation while focusing on the provisions of Articles 3 and 7 and classifying this legal regulation from the perspective of private international law. The part dedicated to the provisions of Article 3 as a norm of international insolvency law introduces the concept of COMI - a basis to determine the jurisdiction of the court that should commence insolvency proceedings. Furthermore, the essential case-law of the CJEU and Czech courts addressing COMI is presented. Regarding Article 7, an opinion is expressed that the legal regulation contained in Article 7 constitutes a conflict-of-laws rule for which the applicable law is determined by the location of the court that opened the given insolvency proceedings. At this point, a fundamental connection is seen between the legal regulation contained in Articles 7 and Article 3. In addition, an opinion is expressed that the legal regulation contained in the Insolvency Regulation leads to the unity of international court jurisdiction and the determination of applicable law, which can be seen as the current trend in European private international law.
\end{abstract}

Keywords: COMI; applicable law; international insolvency law; insolvency regulation; international jurisdiction

DOI: $10.14712 / 23366478.2020 .36$

\section{INTRODUCTION}

The insolvency laws of the individual Member States differ from each other, and thus the issue of the unambiguous determination of applicable law governing insolvency proceedings is of paramount importance, primarily from the perspective of the parties (even potential parties) to the proceedings. The need for the unambiguous determination of applicable law follows from the principle of foreseeability. ${ }^{1}$ In this respect the importance of the foreseeability of the law applicable to insolvency proceedings was expressed also by Advocate General F. G. Jacobs in his opinion in the case

1 In connection with the applicable law provision, the foreseeability principle was mentioned also in CJEU 16 April 2015, Hermann Lutz v Elke Bäuerle, Case C-557/13. 
Eurofood. ${ }^{2}$ In agreement with the Virgos-Schmit Report, ${ }^{3}$ he concluded that insolvency proceedings pose a foreseeable risk and that "it is important that international jurisdiction (which entails the application of the insolvency laws of a given State) be based on a place known to the debtor's potential creditors, thus enabling the legal risks which would have to be assumed in the case of insolvency to be calculated." 4,5

The principle of foreseeability goes hand in hand with the principle of efficiency, which is reflected in Recital $3^{6}$ and Recital $8^{7}$ of the Insolvency Regulation, ${ }^{8}$ as is shown later in this article.

It is thus apparent that it is the setting of clear and foreseeable rules for the determination of international jurisdiction and applicable law that should facilitate the efficient conduct of international insolvency proceedings.

The main rule for determining the applicable law is contained in Article 7 of the Insolvency Regulation. Articles 8 to 18 of the Insolvency Regulation set out exceptions to the general rule of Article 7. A common aspect of all these exceptions is that they regulate situations in which it is necessary to modify the lex fori concursus rule in a certain manner. ${ }^{9}$

The rule set in Article 7 is closely connected to Article 3 of the Insolvency Regulation, which defines COMI and sets up rule for determining the jurisdiction of the court that shall open the insolvency proceedings.

This article aims to analyse the provisions of Article 7 and Article 3 (focusing on the concept of COMI) in terms of their content and relationship and to classify these rules in the context of private international law.

\section{CONFLICT-OF-LAWS RULES VS. JURISDICTIONAL RULES}

The purpose of the conflict-of-laws rules is to determine the applicable law for a given legal relation with an international aspect. A conflict-of-laws rule consists of two parts, namely the scope of application and the determination of applicable law. The scope of application of a conflict-of-laws rule is defined by a sphere of legal rela-

2 Opinion of Advocate General Jacobs, delivered on 27 September 2005, Eurofood IFSC Ltd., Case C-341/04 (hereinafter referred to as "Opinion Eurofood").

3 VIRGOS, M. - SCHMIT, E. Report on the Convention of Insolvency Proceedings. European Union, the Council. Brussels, 3 May 1996, 6500/96.

4 Opinion Eurofood, point 122, Virgos-Schmit Report, Article 75.

5 BRODEC, J. Determination of Applicable Law in International Insolvency Proceedings. In: QUEIROLO, I. - DOMINELLI, S. European and national perspectives on the application of the European insolvency regulation. Rome: Aracne editrice, 2017, p. 85.

6 Recital 3 of the Insolvency Regulation: "The proper functioning of the internal market requires that cross-border insolvency proceedings should operate efficiently and effectively."

7 Recital 8 of the Insolvency Regulation: "In order to achieve the aim of improving the efficiency and effectiveness of insolvency proceedings having cross-border effects, it is necessary, and appropriate, that the provisions on jurisdiction, recognition and applicable law in this area should be contained in a Union measure which is binding and directly applicable in Member States."

8 Regulation (EU) 2015/848 of the European Parliament and of the Council of 20 May 2015 on insolvency proceedings.

9 BRODEC, Determination of Applicable Law in International Insolvency Proceedings, p. 90. 
tions or questions of law (e.g., contractual obligations, inheritance, effects of insolvency proceedings). ${ }^{10}$ The part referred to as the determination of applicable law includes a reference to the relevant law made by means of a connecting factor. ${ }^{11}$

Jurisdictional rules serve for the determination of a state whose courts or other authorities have international jurisdiction to decide defined matters of private law. However, it is impossible to speak of procedural conflict-of-laws rules in general, as at least jurisdictional rules of a national origin do not address the transfer of matters to the jurisdiction of a foreign court, but only define the jurisdiction of the state's own courts. ${ }^{12}$ But a conflict of different state jurisdictions and the determination of a state, whose courts or other authorities have international jurisdiction to decide certain defined matters of private law, are covered by jurisdictional rules contained in international agreements or directly applicable EU legislation. ${ }^{13}$ This determination is made with the use of certain criteria.

The applicable law and jurisdiction can also thus be determined by directly applicable EU legislation including the Insolvency Regulation with the use of certain criteria that are referred to as connecting factors in conflict-of-laws rules or as jurisdictional criteria in jurisdictional rules. Typical connecting factors include, for example, parties' choice and habitual residence ${ }^{14}$ and these can be frequently found as determining criteria also in jurisdictional rules. The seat of the court as a connecting factor is also worth paying attention, ${ }^{15}$ because it clearly unifies jurisdiction and applicable law.

This approach is not incidental, as in European private international law a general tendency can be observed towards the unity of the jurisdiction of the court and applicable law. This unity is a manifestation of the principle of efficiency thanks to which proceedings are not protracted due to the content of foreign law being ascertained, consequently costs are not incurred from such ascertaining. ${ }^{16}$ Examples of legal regulations that are based on the unity of jurisdiction and applicable law include the Succession Regulation ${ }^{17}$ with the uniform criterion being "the habitual residence of the deceased at

10 PAUKNEROVÁ, M. Kolizní norma. In: KUČERA, Z. - PAUKNEROVÁ, M. - RŮŽIČKA, K. a kol. Mezinárodni právo soukromé. 8. vydání. Plzeň - Brno: Vydavatelství a nakladatelství Aleš Čeněk, s. r. o., 2015, p. 104.

11 In addition to a standard conflict-of-laws rules with the above-defined structure there are also atypical conflict-of-laws rules such as the so-called dependent conflict-of-laws rules. A dependent conflict-of-laws rule alone does not lead to the determination of applicable law and, therefore, further conflict-of-laws rules need to be used. Cf. PAUKNEROVÁ, M. Třídění kolizních norem. In: KUČERA, Z. - PAUKNEROVÁ, M. RŮŽIČKA, K. a kol. Mezinárodní právo soukromé. 8. vydání. Plzeň - Brno: Vydavatelství a nakladatelství Aleš Čeněk, s. r. o., 2015, p. 111.

12 RŮŽIČKA, K. Pravomoc tuzemských soudů ve vztahu k zahraničí. In: KUČERA, Z. - PAUKNEROVÁ, M. - RŮŽIČKA, K. a kol. Mezinárodni právo soukromé. 8. vydání. Plzeň - Brno: Vydavatelství a nakladatelství Aleš Čeněk, s. r. o., 2015, p. 353.

13 Ibid.

14 PAUKNEROVÁ, M. Hraniční určovatelé. In: KUČERA, Z. - PAUKNEROVÁ, M. - RŮŽIČKA, K. a kol. Mezinárodni právo soukromé. 8. vydání. Plzeň - Brno: Vydavatelství a nakladatelství Aleš Čeněk, s. r. o., 2015, p. 118.

15 Ibid.

16 SCHWEMMER, S. Anknüpfungsprinzipien im Europäischen Kollisionsrecht. Tübingen: Mohr Siebeck, 2018, pp. 135-136.

17 Regulation (EU) No 650/2012 of the European Parliament and of the Council of 4 July 2012 on jurisdiction, applicable law, recognition and enforcement of decisions and acceptance and enforcement of 
the time of death" or Regulations dealing with divorce issues (Brussels II bis and Rome III) with the uniform criterion of "the habitual residence of the spouses at the time the court is seized". 18

For the sake of completeness, it should be mentioned that jurisdictional criteria or connecting factors found in directly applicable EU legislation need to be subjected to an autonomous interpretation that is independent from national laws. ${ }^{19}$

But one more key question arises from the examples of jurisdictional and conflictof-laws criteria given above. Determination of the content of a given concept (such as habitual residence) is one thing, the time to which the consideration of whether factual circumstances possess the characteristics of the concept should be connected is another. Regarding the determination of international jurisdiction, it can be concluded that a general rule states that the decisive time is the point at which the proceedings are opened and/or when a motion to commence proceedings is lodged. For conflicts-of-laws rules the determination of the decisive time seems to be more diverse. It can be, e.g., the point at which a circumstance that is decisive for the creation of a legal relation occurred (conclusion of a contract) or also the point at which the court is seized (in the case of divorce under the Rome III Regulation). Thus, the Succession Regulation connects the jurisdictional criterion and connecting factor with the time of death of the deceased. The Brussels II bis and Rome III Regulations connect the jurisdictional criterion and connecting factor to the time the court is seized.

In the Insolvency Regulation, the aforementioned temporal aspect is crucial for the determination of COMI. We will address this topic in the next chapter.

\section{COMI - PHENOMENON OF INTERNATIONAL INSOLVENCY LAW}

COMI - the centre of a debtor's main interests - is a cornerstone concept in international insolvency law. On the EU level, two regulations relating to insolvency proceedings with an international aspect have been successively adopted, namely the Bankruptcy Regulation ${ }^{20}$ and the Insolvency Regulation; both use the concept of COMI. In this chapter we will deal with the criteria to be used in determining a debtor's COMI and the importance of COMI for international insolvency proceedings.

authentic instruments in matters of succession and on the creation of a European Certificate of Succession; Article 4 for jurisdiction and Article 21 for applicable law.

18 Council Regulation (EC) No 2201/2003 of 27 November 2003 concerning jurisdiction and the recognition and enforcement of judgments in matrimonial matters and the matters of parental responsibility, repealing Regulation (EC) No 1347/2000, Article 3 for jurisdiction; Council Regulation (EU) No 1259/2010 of 20 December 2010 implementing enhanced cooperation in the area of the law applicable to divorce and legal separation, Article 8 for applicable law.

19 PAUKNEROVÁ, M. Evropské mezinárodní právo soukromé. 2. vydání. Praha: Nakladatelství C. H. Beck, 2013, p. 63-64; CJEU 14 October 1976, LTU Lufttransportunternehmen GmbH \& Co. KG v. Eurocontrol, Case 29-76.

20 Council regulation (EC) No 1346/2000 of 29 May 2000 on insolvency proceedings. 
The concept of COMI is found in Article 3 of the Insolvency Regulation. Unlike in the Bankruptcy Regulation, the term "centre of the debtor's main interests" (COMI) is defined more precisely in the Insolvency Regulation, as Article 3(1) of the Insolvency Regulation was supplemented by the following sentence: "The centre of main interests shall be the place where the debtor conducts the administration of its interests on a regular basis and which is ascertainable by third parties." 21

Furthermore, Article 3 of the Insolvency Regulation contains a rebuttable presumption that the COMI of a company or legal person is where their registered office is situated. In the case of an individual exercising an independent business or professional activity, COMI is presumed to be that individual's principal place of business, and in the case of any other individual, COMI is presumed to be the place of the individual's habitual residence. In order to restrict forum shopping, Article 3 of the Insolvency Regulation was expanded by a rule under which the presumption that COMI is the company's registered office or the principal place of business of an individual exercising an independent business or professional activity "shall only apply if (...) has not been moved to another Member State within the 3-month period prior to the request for the opening of insolvency proceedings." ${ }^{22}$ In the case of any other individuals, that period is extended to six months.

As a result of the insufficient definition of COMI in the Bankruptcy Regulation, courts of the Member States interpreted the concept of COMI in various ways; in particular English courts preferred an interpretation that COMI is the place where the most important decisions relating to the debtor are adopted (the mind-of-management-theory) which did not take into account the ascertainability of COMI by third parties. ${ }^{23}$

However, such an approach was dismissed by the CJEU in its Eurofood ${ }^{24}$ ruling in which the CJEU reached the conclusion that a subsidiary administers its interests as an independent entity in the Member State where its registered office is situated, and in a manner ascertainable by third parties, which cannot be overridden by the fact that the parent company is in a position that it can control the policy of the subsidiary (a $100 \%$ shareholding, power to appoint directors), if this is not ascertainable by third parties, and thus being in direct contradiction to Recital 13 of the Bankruptcy Regulation (currently Article 3 of the Insolvency Regulation). ${ }^{25}$

21 In this manner Recital 13 of the Bankruptcy Regulation was included directly in Article 3 of the Insolvency Regulation.

${ }^{22}$ Cf. Recital 5 of the Insolvency Regulation.

23 GRUBER, P. U. The International Jurisdiction for Main Proceedings: Practical Difficulties in the Application of Art. 3 InsRRecas. In: QUEIROLO, I. - DOMINELLI, S. European and national perspectives on the application of the European insolvency regulation. Rome: Aracne editrice, 2017, pp. 45-46. The author makes a reference to the judgment of the High Court of Justice Leeds no. 861-867/03 of 16 May 2003. See also VAVŘINA, J. COMI v judikatuře českých insolvenčních soudů a pohled do zahraničí. Právní rozhledy, 2012, No. 23-24, pp. 825-829.

24 CJEU 2 May 2006, Eurofood IFSC Ltd., Case C-341/04, (hereinafter referred to as "Eurofood"). Cf. GRUBER, op. cit., pp. 45-46.

25 According to the Opinion Eurofood, point 123 : "strong evidence of overriding and ascertainable control by a parent company would be required." 
Czech courts also take the approach of determining COMI by emphasising its ascertainability by third parties. In two major cases, namely Slovkord ${ }^{26}$ and ECM, ${ }^{27}$ the Regional Court in Brno and the Municipal Court in Prague respectively expressly declared that in considering the question of their international jurisdiction they relied on what is called the head office functions test ${ }^{28}$ which is a test of management powers conducted on the basis of objective facts that are ascertainable by third parties. During this test, the courts assessed the following criteria: the place where commercial policy is determined and funds obtained, the place of negotiations with strategic partners, and the place of administration of personnel policy, bookkeeping and the administration of information systems. The courts furthermore examined a second condition for their jurisdiction, i.e., whether the Czech Republic as the place where they administer their interests on a regular basis is ascertainable also by third parties. When assessing this condition the courts took into account the following facts, for example: the address stated as the contact address for creditors, the address at which the company was contacted by business partners, and where negotiations with most creditors took place. ${ }^{29}$

In the Interedil ${ }^{30}$ ruling the CJEU followed up the Eurofood approach and specified more precisely a procedure for determining COMI and handling defined rebuttable presumptions. In this ruling the CJEU defined the basic steps, namely (i) ascertaining whether the central administration of a company (decision-making by the bodies responsible for the management of and supervision over a company) takes place in the Member State where the company's registered office is situated, and (ii) whether this fact is ascertainable by third parties, ${ }^{31}$ and if not, the court should proceed with (iii) the overall assessment of all relevant factors relating to the company including the place where the company pursuits an economic activity, the localisation of its assets etc. Also in the case of the third step, it is crucial for third parties to have the possibility to check that "the company's actual centre of management and supervision and of the management of its interests is located in that other Member State" - i.e., other than where the company's registered office is situated. ${ }^{32}$

In its judgments the CJEU emphasised that the concept of COMI is peculiar to the Bankruptcy and/or the Insolvency Regulation and that it therefore has a separate meaning and needs to be interpreted in a uniform way, independently of national legislation. ${ }^{33}$

26 Ruling of the Regional Court in Brno no. KSBR 39 INS 2464/2009-A-12 of 14 May 2010.

27 Ruling of the Municipal Court in Prague no. MSPH 79 INS 6021/2011-A-24 of 24 May 2011.

28 In the past this test was adopted also in other EU Member States such as England (in the ruling of the High Court of Justice, Chancery Division Leeds District Registry in the case Daisytek - ISA Ltd. of 16 May 2003), Germany (in the ruling of the Amtsgericht München in the case Hettlage AG \& Co KG, Innsbruck of 4 May 2004), and also France (in the judgment of the Tribunal du commerce de Nanterre of 15 June 2006 in the case Emtec Consumer Media Benelux Nv). See decision of the Municipal Court in Prague no. MSPH 79 INS 6021/2011-A-24 of 24 May 2011.

29 From the perspective of the value of the creditor's claims.

30 CJEU 20 October 2011, Interedil Srl, vin liquidation v. Fallimento Interedil Srl and Intesa Gestione Crediti SpA, Case C-396/09 (hereinafter referred to as "Interedil").

31 If this condition is met, COMI is situated in the Member State where the company's registered office is situated and this presumption set out in Article 3(1), second sentence of the Bankruptcy Regulation cannot be rebutted.

32 Interedil ruling, point 53.

33 Eurofood ruling, point 31; Interedil ruling, point 42. 
This is why for its interpretation which should be independent, the specification of this concept in the Insolvency Regulation and the CJEU case-law is of crucial importance. The importance of the interpretation and application of this determinant is stressed by the fact that it is not a concept the fulfilment of which can be proven, e.g., by an entry in a register. Indeed, in the case of COMI the matter of fact is finally given priority, i.e., the place of the debtor's actual activity and the perception of the debtor's centre by the creditors. The approach taken is a compromise between legal certainty and flexibility in ascertaining COMI.

An important question the CJEU also dealt with is the time at which the debtor's COMI is determined. ${ }^{34}$ In simple terms, COMI is ascertained at the time when the request to open insolvency proceedings was lodged, or, at the time when the debtor ceases to exist (i.e., the last place of the debtor's activity). ${ }^{35} \mathrm{~A}$ transfer of COMI after the lodging of a request does not affect international jurisdiction and its transfer before a request is lodged also does not change anything regarding the manner of ascertaining COMI. ${ }^{36}$

\subsection{THE IMPORTANCE OF COMI IN INTERNATIONAL INSOLVENCY LAW}

We come across the concept of COMI only in international insolvency law, as it is not known to any other field relating to private international law. However, in international insolvency law COMI is of crucial importance for tackling several questions of law.

Article 3 of the Insolvency Regulation is primarily a norm of international procedural law, as COMI is a criterion for determining the international jurisdiction of a court for opening main insolvency proceedings. ${ }^{37}$ The location of COMI also determines the scope of application of the Insolvency Regulation. If the debtor's COMI is located outside the $\mathrm{EU}$, the insolvency proceedings are excluded from the applicability of the Insolvency Regulation. ${ }^{38}$ But the importance of COMI extends even further. Another sphere of international insolvency law impacted by COMI is the subject of the next chapter.

\section{ARTICLE 7 AND LEX FORI CONCURSUS}

\subsection{PRINCIPLE LEX FORI CONCURSUS AS A GENERAL RULE}

The basic rule of the Insolvency Regulation relating to the determination of applicable law is set out in Article 7, pursuant to which the law applicable to insolvency proceedings and their effects (lex fori concursus) is the law of the Member State

34 CJEU 17 January 2006, Susanne Staubitz-Schreiber, Case C-1/04 (hereinafter referred to as "Staubitz") and the Interedil ruling.

35 Staubitz ruling, point 29.

36 Interedil ruling, point 54 et seq.

37 The Insolvency Regulation establishes only international jurisdiction; however, territorial jurisdiction within a Member State should be established by the national law of the Member State concerned. See Recital 26 of the Insolvency Regulation.

38 Recital 25 of the Insolvency Regulation. 
within whose territory such insolvency proceedings were commenced, unless otherwise provided by the Insolvency Regulation.

The main rule provided in Article 7 of the Insolvency Regulation is identical to the rule in Article 4 of the Bankruptcy Regulation. The differences between the Bankruptcy Regulation and the Insolvency Regulation regarding applicable law relate only to the exceptions, which are not the topic of this article.

The rule determines which law is to be applied to insolvency proceedings during their entire conduct, i.e., which law is to be applied in considering the conditions for the opening of those proceedings, their conduct, and their closure. Since this rule can be considered in EU law as a uniform rule for insolvency proceedings involving an international aspect, it can be derived, that this rule replaces within its scope of application national rules of private and procedural international laws of the individual EU Member States.

A reference pursuant to Article 7 is made to the national law of a particular EU Member State with the exception of rules of national private international law, thus renvoi is not permitted. ${ }^{39}$

Regarding the content of unifying provisions on conflict of laws relating to the applicable law, remission and transmission are excluded. However, these rules on conflict of laws are not of a universal nature. Regarding the territorial applicability of the Insolvency Regulation these rules may refer only to the law of a certain Member State. In relation to third states it will still be necessary to use the rules of national or international law, which regulate these matters. ${ }^{40}$

The applicable law determined under Article 7 of the Insolvency Regulation has a universal effect on the entire proceedings. Thus the lex fori concursus as the rule for a uniform main insolvency statute purports to apply one law to the entire insolvency proceedings which will govern substantive and procedural questions relating to the insolvency proceedings. ${ }^{41,42}$ In Article 7(2) of the Insolvency Regulation, questions to which the lex fori concursus principle is in particular to be applied are demonstratively set out; these questions include for example which assets form part of the insolvency estate or the rules governing the lodging, verification and admission of claims. ${ }^{43}$

39 MOSS, G. - FLETCHER, I. F. - ISAAC, S. Moss, Fletcher and Isaacs on the EU regulation on insolvency proceedings. Third edition. Oxford: Oxford University Press, 2016, p. 339.

40 PAUKNEROVÁ, M. Evropské mezinárodní právo soukromé. 2. vydání. Praha: Nakladatelství C. H. Beck, 2013, p. 224.

41 EU Council: Report on the Convention of Insolvency Proceedings, Brussels, 3 May 1996, 6500/96, Art. 90.

42 BRODEC, Determination of Applicable Law in International Insolvency Proceedings, p. 89.

43 The lex fori concursus determines in particular: (a) the debtors against which insolvency proceedings may be brought on account of their capacity; (b) the assets which form part of the insolvency estate and the treatment of assets acquired by or devolving on the debtor after the opening of the insolvency proceedings; (c) the respective powers of the debtor and the insolvency practitioner; (d) the conditions under which setoffs may be invoked; (e) the effects of insolvency proceedings on current contracts to which the debtor is party; (f) the effects of the insolvency proceedings on proceedings brought by individual creditors, with the exception of pending lawsuits; ( $g$ ) the claims which are to be lodged against the debtor's insolvency estate and the treatment of claims arising after the opening of insolvency proceedings; (h) the rules governing the lodging, verification and admission of claims; (i) the rules governing the distribution of proceeds from the realisation of assets, the ranking of claims and the rights of creditors who have obtained partial satisfaction after the opening of insolvency proceedings by virtue of a right in rem or through a set-off; (j) the conditions for, and the effects of closure of, insolvency proceedings, in particular by composition; 
It is important to emphasise that the CJEU confirmed the broadest possible application of the lex fori concursus to all questions that may arise in the main insolvency proceedings. ${ }^{44,45}$

However, certain precisely defined issues (i.e., cases "otherwise provided" for in the Insolvency Regulation) are subject to other applicable law. These exceptions to the basic lex fori concursus rule are enumerated in Articles 8 to 18 of the Insolvency Regulation.

However, it is necessary to note that irrespective of the absence of an express regulation in the Insolvency Regulation, the rules enshrined in Articles 7 to 18 of the Insolvency Regulation will not apply to the determination of a law applicable to questions which arise in main or secondary insolvency proceedings but to which such proceedings are not linked in any specific manner. The law applicable to such questions will be determined under the rules of private international law of the relevant Member State which are otherwise applicable. ${ }^{46}$ Thus, it is necessary to apply the insolvency statute only to questions which are closely related to the relevant international insolvency proceedings. It is therefore necessary to analyse, whether a given insolvency is only a precondition of the facts of the case or whether the rules alone serve directly the purposes of insolvency proceedings (such as the equal treatment of creditors). ${ }^{47}$

It can be concluded that Article 7 of the Insolvency Regulation constitutes a norm having an aspect of rules on the conflict of laws, as it determines the applicable law for substantive questions in international insolvency proceedings but, as we believe, it also possesses the characteristics of international procedural law, as it determines the rules under which given international proceedings will be conducted. ${ }^{48}$

\subsection{ARTICLE 7 AND ARTICLE 3 AND THEIR ASPECTS AS NORMS OF PRIVATE INTERNATIONAL LAW}

First of all, it should be emphasised that insolvency law as such is not only procedural law; rather, it is a set of norms of a procedural and substantive nature. ${ }^{49}$ It can be stated that procedural norms in insolvency law prevail in particular with regard to the fact that insolvency law should regulate how the court and insolvency administrator are

(k) creditors' rights after the closure of insolvency proceedings; (1) who is to bear the costs and expenses incurred in the insolvency proceedings; $(\mathrm{m})$ the rules relating to the voidness, voidability or unenforceability of legal acts detrimental to the general body of creditors.

44 CJEU 9 November 2016, ENEFI Energiahatékonysági Nyrt v Direcția Generală Regională a Finanțelor Publice Brașov (DGRFP), Case C-212/15.

45 The same opinion can be found, e.g., in DUURSMA-KEPPLINGER, H.-Ch. - DUURSMA, D. - CHALUPSKY, E. Kommentar - Europäische Insolvenzverordnung. 1st edition. Vienna: Springer Verlag, 2002, Article 4, no. 15. On the other hand, some authors urge forbearance in this respect: BĚLOHLÁVEK, A. J. Evropské a mezinárodni insolvenčni řizení. Komentár k nařizeni EP a Rady (EU) 2015/848 o insolvenčním rízení. Praha: Nakladatelství C. H. Beck, 2020, p. 256.

46 DUURSMA-KEPPLINGER - DUURSMA - CHALUPSKY, op. cit., Article 4, no. 6.

47 ČIHULA, T. Aktuálni otázky insolvenčního řizeni s cizím prvkem. Dissertation. Prague: Charles University, Faculty of Law, 2007, p. 71, with reference to Virgos-Schmit Report, Article 90. See also CJEU 2 July 2009, SCT Industri, Case C-111/08, point 21: "[...] an action is related to bankruptcy if it derives directly from the bankruptcy and is closely linked to proceedings for realising the assets or judicial supervision."

48 BRODEC, Determination of Applicable Law in International Insolvency Proceedings, p. 88.

49 BĚLOHLÁVEK, op. cit., p. 252. 
supposed to proceed. However, it is also possible to identify certain typical questions and concepts of substantive law that are regulated by insolvency law.

A typical concept of substantive law that is regulated in insolvency proceedings is the admissibility of a bankrupt's setting off his claims against the claims of his contractual partners as provided, e.g., in the provisions of Section 140 of the Czech Insolvency Act. ${ }^{50}$ Another question of this kind is the ineffectiveness of legal acts as regulated, e.g., in the provisions of Section 235 et seq. of the Insolvency Act. This occurs in a situation in which a certain legal act towards the bankrupt is inefficient, i.e., the bankrupt's contracting partner is obligated to surrender performance obtained through an ineffective legal act to the bankruptcy estate. Important questions of substantive law dealt with in insolvency proceedings that should be mentioned include the liability of members of a debtor's governing body for belated lodging of a request to open insolvency proceedings which is regulated in the provisions of Sections 98 and 99 of the Insolvency Act.

Above we presented the opinion that Article 7 can be considered a norm for a conflict of laws and for international procedural law. In this connection it is important to make a reference to certain specifics of Article 7 as a conflict-of-laws rule.

Article 7 as a conflict-of-laws rule has its scope of application and its part referring to the applicable law including a connecting factor. Article 7 (1) can be considered as a general definition of the substantive part. Article 7 (2) sets out questions to which the law determined pursuant to Article 7 (1) should apply. Because as mentioned above, Article 7 should be applied as broadly as possible to questions relating to insolvency proceedings, the list provided in Article 7 (2) must be considered as demonstrative.

The situation is rather more complicated as concerns a connecting factor. Regarding the determination of applicable law, Article 7 refers to the law of the Member State within the territory of which insolvency proceedings are opened. The rule for determining international jurisdiction for opening insolvency proceedings is contained in the previously mentioned Article 3 and is based on the determination of COMI.

It is important to note that the legal literature presents opinions that COMI itself is a connecting factor for the determining of applicable law. ${ }^{51}$ If we take the definition of a connecting factor as a fact contained in the part of the conflict-of-laws rule referring to the applicable law and creating the closest link to a given legal relation, then we arrive at a different conclusion. Article 7 refers to the law of the Member State within the territory of which insolvency proceedings are opened as an applicable law. Thus, we can opine that the connecting factor for the determination of applicable law under Article 7 as a conflict-of-laws rule is the seat of the court that opened the proceedings. $^{52}$

50 Act No. 182/2006 Coll., the Insolvency Act (hereinafter referred to as "Insolvency Act").

51 RINGE, W.-G. Insolvency Forum Shopping, Revisited. In: LAZIĆ, V. - STUIJ, S. Recasting the insolvency regulation: improvements and missed opportunities. Hague: T.M.C. Asser Press, 2020, p. 2.

52 For simplification, we refer to the court's seat as a connecting factor despite a different formulation in Article 3 of the Insolvency Regulation which does not mention directly the court's seat but refers to the law of the Member State within the territory of which insolvency proceedings were opened. The reason for this formulation may be the fact that pursuant to Article 4 (2) of the Insolvency Regulation, insolvency proceedings may be opened even without a court ruling. 
The court which shall have the jurisdiction to open the insolvency proceedings is to be determined pursuant to Article 3 of the Insolvency Regulation by the COMI location. This suggests that Article 3 of the Insolvency Regulation has the function of a norm of international procedural law on the one hand, and leads to the determination of a connecting factor for establishing the applicable law for insolvency proceedings ${ }^{53}$ on the other. Lex fori concursus will be the law that has the closest link to the given insolvency proceedings. ${ }^{54}$

As the determination of international jurisdiction and subsequently the determination of applicable law will be based on the same objective facts, i.e., on COMI, there will be unity of international jurisdiction and applicable law. Therefore, it is important for the determination of COMI to be objectively predictable in advance, as it is important not only to determine in advance which court has international jurisdiction, but also which substantive law is applicable based on the conflict-of-laws rule in Article 7.55 This may be of crucial importance for a debtor's (company's) governing bodies whose responsibility for the period preceding the opening of insolvency proceedings will be considered in accordance with the law to be determined on the basis of COMI ascertained at the point when a request for opening insolvency proceedings is lodged. If COMI is not defined so as to provide sufficient legal certainty regarding its location, the governing bodies may hardly fulfil their duties, if it is not known to them which law lays down such duties (e.g., the aforementioned duty to lodge a request to open insolvency proceedings in a timely manner) ${ }^{56}$

The stipulation of unity of jurisdiction and applicable law in the Insolvency Regulation can be regarded as an expression of the principle of efficiency, as set out in Recitals 3 and 8 of the Insolvency Regulation.

\section{CONCLUSION}

This article analysed the content of Articles 7 and 3 of the Insolvency Regulation and their classification as norms of private international law. Furthermore, the inherent interconnectedness between Articles 7 and 3 was pointed out.

Article 7 can be described as a norm having the nature of an international procedural law norm and, at the same time, a conflict-of-laws rule. This is due to the fact that it determines the law that is applicable to procedural questions of international insolvency proceedings and, at the same time, it stipulates the governing law which should be applied to substantive questions relating to international insolvency proceedings.

53 See also BĚLOHLÁVEK, op. cit., 2020, p. 254.

54 Ibid., p. 253.

55 KOKORIN, I. Contracting Around Insolvency Jurisdiction: Private Ordering in European Insolvency Jurisdiction Rules and Practices. In: LAZIĆ, V. - STUIJ, S. Recasting the Insolvency Regulation Improvements and Missed Opportunities. Hague: T.M.C. Asser Press, 2020, pp. 25-26.

56 BRODEC, J. Určení COMI v př́ípadě přeshraničního insolvenčního řízení a jeho vliv na určení rozhodného práva ohledně odpovědnosti členů statutárních orgánů úpadce. In: Rekodifikace obchodního práva - pět let poté. Svazek I. Pocta Stanislavě Černé. Praha: Wolters Kluwer, 2019, p. 90. 
For the determination of the law applicable to substantive questions, the connecting factor under Article 7 is the seat of the court which opened the international insolvency proceedings. In this respect a connection can be seen between Articles 3 and 7 of the Insolvency Regulation. As a matter of fact, Article 3 operates as a norm of international procedural law for the determination of international jurisdiction, and for the determination of a connecting factor for the reference to applicable law under Article 7.

In the above context, the importance of COMI was also pointed out as a specific concept of international insolvency law. COMI leads to the determination of international jurisdiction but it is important also for the determination of the law applicable to substantive-law matters relating to international insolvency proceedings. Hence, it is crucial for COMI to be determined based on unambiguous, determinate, and objectively ascertainable criteria in compliance with the requirement of foreseeability of applicable law for insolvency proceedings.

The aforementioned interconnectedness between the determination of international jurisdiction and applicable law in insolvency proceedings leads to unity in the determination of international jurisdiction and applicable law which can be seen as a current trend in the European norms of private international law.

JUDr. Jan Brodec, LL.M. Ph.D.

Faculty of Law, Charles University, Prague

brodec@prf.cuni.cz 